\title{
Cartografias da cidadania diferenciada em Luiz Ruffato e Guillermo Saccomanno
}

Leila Lehnen

\begin{abstract}
RESUMO: O ensaio examina a relação entre o espaço urbano e a constituição e/ou a erosão da cidadania em seleções da coleção Inferno provisório, de Luiz Ruffato, e na novela El pibe, do escritor argentino Guillermo Saccomanno. Esses textos traçam uma cartografia literária dos espaços proletários e dos direitos cidadãos (assim como da falta destes) associados a esses espaços. Os livros demonstram - ficcionalmente - o processo dinâmico da cidadania, sua implementação desigual e como a cartografia material e imaginária reflete, reforça e, por vezes, questiona estas configurações.
\end{abstract}

PALAVRAS-CHAVE: Cidadania; cidade; desigualdade social; Luiz Ruffato; Guillermo Saccomanno

ABSTRACT: This essay examines the relation between urban space and the constitution and/or the erosion of citizenship in selected stories of Luiz Ruffato's Inferno provisório and Guillermo Saccomanno's novella El pibe. These texts draw a literary cartography of the working class spaces and of the citizenship rights (and the lack thereof) associated with these terrains. The books reveal, at the fictional level, the dynamic process of citizenship, its unequal implementation and how the material and symbolic cartography reflects, reinforces and, at times, questions these configurations. 
Qual é a correlação entre cidade e cidadania? Em sua introdução ao volume Cities and Citizenship (1999), Arjun Appadurai e James Holston focalizam a ligação entre a configuração da cidadania e o espaço urbano. Ambos identificam a esfera urbana como uma "arena estratégica para o desenvolvimento da cidadania.". Sugerem que os espaços urbanos, em especial aqueles que são palco de engajamento cívico, são propícios para a demanda de vários tipos de direitos, como o voto direto ou a reivindicação de transporte público mais acessível.

No entanto, para os autores a cidade não é apenas um lugar para o desenvolvimento da cidadania. Sua geografia é também caracterizada por setores de privação de direitos tanto materiais como simbólicos. ${ }^{2}$ Nessas zonas privativas de direitos, os direitos sociais, civis, políticos e culturais são enfraquecidos ou desaparecem completamente. Favelas, villas miserias, barriadas, poblaciones, algumas das denominações usadas para designar zonas metropolitanas pobres em vários países latino-americanos, são territórios prototípicos de exclusão, locais onde a cidadania diferenciada ${ }^{3}$ se torna claramente evidente. Holston define a cidadania diferenciada como uma expressão de "cidadania que administra as diferenças sociais, legalizando-as de maneiras que legitimem e reproduzam a desigualdade". ${ }^{4}$ Em outras palavras, a cidadania diferenciada justifica diferenças socioeconômicas através de meios legais. Pode-se dizer que a cidadania diferenciada é um dos resultados do que Holston denomina "democracias disjuntivas", caracterizadas por uma distribuição desigual dos direitos associados às três esferas da cidadania: as dos direitos políticos, sociais e cívicos. ${ }^{6}$

1. Appadurai, Arjun; holston, James (Orgs.). "Introduction: Cities and Citizenship". In: Cities and Citizenship. Durham: Duke UP, 1999, p. 2. Esta e todas as traduções do autor.

2. Ver a respeito Caldeira, Teresa P. R. City of Walls. Crime, Segregation, and Citizenship in São Paulo. Berkeley: University of California Press, 200o. Top of Form

3. HOLston, James. Insurgent Citizenship. Disjunctions of Democracy and Modernity in Brazil. New Jersey: Princeton University Press, 2008.

4. Id., pp. 3-4.

5. HOLston, James. "Citizenship in Disjunctive Democracies". In: TUlChIn, Joseph S. and RUthenburg, Meg (Orgs.). Citizenship in Latin America. Boulder, Colo: Lynne Rienner Publishers, 2007, pp. 75-94.

6. marshall, T. H. Citizenship and Social Class, and Other Essays. Cambridge: Cambridge University Press, 1950 . 
Entre os territórios de privilégio e as zonas de privação de direitos, existem entre -espaços urbanos onde os cidadãos possuem algum poder, mas são predominantemente marginalizados. Nesses territórios a cidadania substantiva está sob (re)negociação contínua. Esses entre-espaços são o cenário para as representações que o escritor brasileiro Luiz Ruffato e o ficcionista argentino Guillermo Saccomanno fazem da vida proletária urbana em seus respectivos países. No ciclo de cinco "romances" Inferno provisório (2005-2011) e na novela El pibe (O garoto, 2006), Ruffato e Saccomanno transformam as classes trabalhadoras brasileira e argentina em protagonistas improváveis de nações em crise. Ainda que não tenham sido os primeiros a abordarem a classe trabalhadora nas literaturas brasileira e argentina - pense-se, por exemplo, nas obras de Aluísio de Azevedo e de Patrícia Galvão, no Brasil, ou de Roberto Arlt e de Manuel Puig, na Argentina -, ao focá-la em seus textos, tanto a obra de Ruffato como a de Saccomanno estão na contramão do romance tradicional nos dois países, já que este, em geral, enfoca personagens burguesas. ${ }^{7}$

Este ensaio examina a conjunção entre o espaço urbano e a constituição e/ou erosão da cidadania em histórias em fragmentos selecionados de Inferno provisório e de El pibe. Em ambos os textos, a cidade torna-se o epicentro das aspirações sociais das classes trabalhadoras que protagonizam os dois livros. É onde a sua cidadania se materializa (na forma de empregos estáveis, a casa própria, educação pública e espaços públicos que são usados para o lazer, para a mobilização política, entre outras coisas).

No entanto, as narrativas de Ruffato e de Saccomanno também revelam a precariedade da cidadania social - o acesso a bens como saúde e educação pública - das classes trabalhadoras, resultado tanto no Brasil como na Argentina da formulação disjuntiva dos direitos sociais, civis e políticos. Inferno provisório e El pibe demonstram o impacto desestabilizador que a alocação diferenciada dos direitos sociais, civis e políticos exerce sobre o referido segmento social. Os bairros proletários descritos nos textos de Ruffato e Saccomanno são, assim, zonas fronteiriças da cidadania, lugares onde os marcadores de pertencimento nacional coexistem com as manifestações de exclusão socioeconômica que conotam a marginalização material da classe trabalhadora em relação ao projeto nacional.

7. Hollanda, Heloísa Buarque de. "Literatura com um projeto". Revista Z. Revista do Programa Avançado de Cultura Contemporânea. Rio de Janeiro, 3, 1, 2006. Disponível em: http://revistazcultural.pacc.ufrj. br/literatura-com-um-projeto-entrevista-com-heloisa-buarque-de-holanda/. Acesso em: 3 abr. 2010. 
Os dois livros revelam assim, no nível ficcional, o processo dinâmico da cidadania e sua implementação desigual no espaço urbano latino-americano. Ambos os textos mostram como a cartografia material (os territórios onde se desenvolvem as narrativas) e simbólica (como o espaço é entendido) reflete e reforça tanto as reivindicações como as disjunturas da cidadania. Ou seja, nas suas histórias, os dois escritores destacam a importância do espaço urbano na vida econômica e social das classes trabalhadoras no Brasil e na Argentina.

A ênfase que as obras de Ruffato e Saccomanno põem sobre personagens proletários e os espaços pelos quais estes transitam reflete uma atenção crescente na literatura latino-americana contemporânea à temática da cidadania após as transições democráticas da década de 1980 (1983 na Argentina, 1985 no Brasil). Este interesse na formulação e na precariedade da cidadania se reflete também na tematização de setores e espaços sociais marginalizados dentro de várias produções literárias e cinematográficas de ambos os países. Há, sem dúvida, um certo voyeurismo do abjeto em certas dessas produções culturais, com suas representações muitas vezes hiper-realistas de violência, pobreza e, muitas vezes aliada à última, da criminalidade. Em contraste com esse tipo de abordagem, os livros de Ruffato e de Saccomanno evitam o sensacionalismo ou a estetização da violência/pobreza/criminalidade. ${ }^{8}$ Em vez disso, Inferno provisório e El pibe sugerem uma violência estrutural. Os dois livros descrevem as iniquidades de um cotidiano marcado pelo empobrecimento material e simbólico: o pai que tem de pedir dinheiro emprestado para comprar remédios para o seu filho doente (El pibe 95), o trabalho opressivo e mal remunerado em fábricas (Inferno provisório). A cidadania diferenciada nos dois romances diz respeito não apenas à penúria material, mas refere-se também a horizontes existenciais limitados, ao desmoronamento gradual de esperanças, expectativas de vida e sonhos dos personagens dos dois textos. Nesse sentido, os textos de Saccomanno e de Ruffato refletem uma mudança na forma como a cidadania é definida na literatura latino-americana.

Tradicionalmente a cidadania sugere a ideia de pertencimento a uma determinada comunidade política, $\mathrm{o}$ acesso a um conjunto de direitos, assim como ser sujeito a uma série de obrigações para com a comunidade à qual se pertence. Hoje em dia predo-

8. BeNTES, Ivana. “The Aesthetics of Violence in Brazilian Film”. In: vieIRA, Else (Org.). City of God in Several Voices: Brazilian Social Cinema as Action. Nottingham: Critical, Cultural and Communication Press, 2005, pp. 82-92. 
mina a definição liberal da cidadania. Esta se baseia na ideia da igualdade, da liberdade individual e atribui ao Estado a responsabilidade de garantir os direitos individuais. ${ }^{9}$

Desde o influente ensaio, ainda que controverso, do sociólogo britânico T. H. Marshall, "Citizenship and Social Class", a cidadania se define a partir de três dimensões: os direitos sociais (tais como acesso à educação e saúde), os direitos políticos (como a representação política) e os direitos civis (tal como a representação legal). Cada vez mais, no entanto, a cidadania engloba uma dimensão cultural, que inclui o direito à autorrepresentação por parte de grupos tradicionalmente marginalizados, tais como minorias étnicas, sociais, mulheres, membros da comunidade LGBT, entre outros. A literatura pode se tornar um instrumento através do qual estes e outros grupos podem ganhar visibilidade e expressar suas preocupações e suas demandas de melhoria social. Em outras palavras, a literatura pode se tornar uma ferramenta e uma expressão de cidadania.

Ruffato e Saccomanno veem na literatura uma forma de se aproximar simbolicamente e interrogar de maneira crítica as condições sociais que geram e perpetuam a desigualdade. Em entrevista à jornalista e escritora Eliane Brum, Luiz Ruffato vê na literatura uma ferramenta para a transformação social - e se profere seguidor da "Igreja do Livro Transformador". ${ }^{10}$ Já Saccomanno divisa na literatura uma crônica parcial, ainda que contundente, de certas condições sociopolíticas. Para Saccomanno, "é evidente que a narrativa (literária) muitas vezes é capaz de retratar melhor os fenômenos políticos e sociais que os textos históricos". ${ }^{11}$

Semelhantemente a algumas das narrativas que compõem Inferno provisório, El pibe baseia-se em material autobiográfico para traçar um esboço do proletariado da Argentina. Para o jovem protagonista da novela, os livros (ou seja, a literatura) são "medios para un cambio de consciencia, una 'Superación". ${ }^{12} \mathrm{O}$ texto literário, que se inspira nas condições que geram a cidadania diferenciada, serve para criticar e superar essas condições simbolicamente.

9. Yashar, Deborah J. “Citizenship Regimes, the State, and Ethnic Cleavages". In: TUlchin, Joseph S. and RUthenburg, Meg (Orgs.). Citizenship in Latin America. Boulder: Lynne Rienner, 2007, pp. 59-74. 10. BRUM, Eliane. "A Igreja do Livro Transformador". Revista Época, 31 jan. 2011. Disponível em: http://revistaepoca.globo.com/Revista/Epoca/o,EMI206842-15230,oo-A+IGREJA+DO+LIVRO+TRANSFORMADOR.html. Acesso em: 5 mar. 2012.

11. Costa, Flavia. "La patria de los rencores". Clarín, 6 set. 2003. Disponível em: http://edant.clarin. com/suplementos/cultura/2003/o9/06/u-oo611.htm. Acesso em: 6 jul. 2012.

12. Saccomanno, Guillermo. El pibe. Buenos Aires: Planeta, 2006, p. 47. 


\section{A CARTOGRAFIA DO PURGATÓRIO: INFERNO PROVISÓRIO DE LUIZ RUFFATO}

Inferno provisório é paradigmático do engajamento social que transparece de uma "literatura do desencanto", ${ }^{13}$ textos que denunciam circunstâncias sociais adversas e abordam a dificuldade - ou a impossibilidade - de transformar essas condições. Estruturado em cinco volumes (Mamma, son tanto felice, 2005; O mundo inimigo, 2005; Vista parcial da noite, 2006; O livro das impossibilidades, 2008; e Domingos sem deus, 2011), ${ }^{14}$ Inferno provisório abrange cerca de cinco décadas da história nacional, dos anos 1950 até a contemporaneidade. Os cinco volumes fogem a uma classificação de gênero específica. As histórias que fazem parte da pentalogia podem ser lidas como um romance, com histórias ora interligadas, ora complementárias, porém por vezes desconexas, ou como uma coleção de contos.

Este ensaio se limitará aos volumes 1 a 4 da coleção. Embora todos os tomos enfoquem personagens de trabalhadores, os primeiros quatro livros centralizam essa classe de forma mais evidenciada. Especificamente, os primeiros quatro livros de Inferno provisório abordam a transformação do Brasil de uma economia agrária para uma industrializada e a inserção problemática do país - e de seus trabalhadores - em um mundo globalizado (no sentido neoliberal). Essa transformação é descrita a partir das vidas e das tragédias pessoais e sociais dos diferentes personagens, todos eles pertencentes à classe trabalhadora. No entanto, é importante frisar que esses personagens não representam uma classe no sentido marxista. Ou seja, na sua grande maioria não têm consciência de pertencimento a uma classe social, nem compartem uma agenda para avançar os interesses de tal classe. Nesse sentido, embora vários dos trabalhadores de Inferno provisório constituam parte da economia formal, trabalhando como operários em fábricas ou no comércio, seu modo de pensar se assemelha mais ao do lumpemproletariado marxista.

O cenário dos primeiros quatro volumes de Inferno provisório é principalmente a cidade natal de Ruffato, Cataguases, no sudeste de Minas Gerais. Tomados em conjunto,

13. LeHnen, Leila. Citizenship and Crisis in Contemporary Brazilian Literature. New York: Palgrave Macmillan, 2013.

14. Cf. Ruffato, Luiz. Mamma, son tanto felice. Rio de Janeiro: Record, 2005; O mundo inimigo. Rio de Janeiro: Record, 2005; Vista parcial da noite. Rio de Janeiro: Record, 2006; O livro das impossibilidades. Rio de Janeiro: Record, 2008; Domingos sem deus. Rio de Janeiro: Record, 2011. 
os quatro volumes desenham um mapa complexo de Cataguases, que inclui suas áreas centrais, os seus arredores rurais e suburbanos, e se estende até aglomerados urbanos maiores, como Rio de Janeiro, Santos e São Paulo. Esses lugares estão ligados uns aos outros pelos movimentos físicos dos personagens dos livros e pelo tráfego figurativo dos sonhos e decepções que circulam entre os vários espaços através de personagens migrantes - ou que desejam migrar, como o personagem Dinim, da história "Zezé e Dinim" (O livro das impossibilidades). Assim, a valência simbólica de cada território, seja este urbano ou rural,é ambivalente, prenhe de esperança e de desencanto. Por um lado, o perímetro urbano representa, em relação ao rural, um progresso socioeconômico, mas também a negação das aspirações que representa. Por outro lado, o campo é uma metáfora tanto da estagnação socioeconômica (que motiva o êxodo rural) quanto de um passado idealizado.

O primeiro volume do ciclo, Mamma son tanto Felice, narra a migração das zonas rurais para as urbanizações menores, como Rodeiro, Ubá, e Muriaré, que cercam o perímetro urbano de Cataguases. No segundo volume, $O$ mundo inimigo, os personagens passaram de pequenas cidades ao redor de Cataguases a esta. Eles habitam áreas pobres de Cataguases (embora localizadas na região central da cidade). O Beco do Zé Pinto, um cortiço que serve de palco para uma porção significativa da obra, é a sinédoque desses lugares. Vista parcial da noite traça o deslocamento dos bairros centrais pobres para a periferia urbana, para a qual a classe trabalhadora migra em busca de ascensão social. Essa ascensão é exemplificada no sonho (ainda que precário) da casa própria, adquirida muitas vezes por meio da autoconstrução. No entanto, as histórias desse volume evidenciam que o movimento do centro da cidade para a periferia, em última instância, não oferece a tão almejada ascensão social. O movimento migratório se completa em O livro das impossibilidades, no qual os personagens deixam Cataguases e sua periferia à procura de melhores oportunidades socioeconômicas nos centros metropolitanos, como Rio de Janeiro e Santos, onde se instalam em bairros pobres e/ou industriais na periferia urbana, reproduzindo o padrão sociogeográfico de marginalização que causou a sua emigração, primeiramente do campo e, depois, de Cataguases. Finalmente, em Domingos sem deus, encontramos os personagens de Ruffato estabelecidos nas metrópoles do Sudeste brasileiro. Como nos outros tomos, nós nos deparamos com seres desencantados, cansados e alienados. Rotos os laços familiares e de sociabilidade que ainda existiam nas comunidades de origem, os personagens de Domingos sem deus são sujeitos solitários que deambulam a esmo pela cidade grande.

A violência, ou melhor, diferentes modalidades de violência, tanto doméstica como pública, é tema recorrente em todos os cinco livros de Inferno provisório. Ela 
estabelece as coordenadas simbólicas da cartografia dos livros e indica a privação de direitos sociais da qual é vítima grande parte dos personagens. Muitas vezes, a violência se transfere de um âmbito espaçotemporal a outro, perseguindo os personagens como uma sombra. Paradigmática é a história "A expiação" (de Mamma son tanto felice). Nessa narrativa, o legado da violência cometida pelos seus personagens se perpetua por duas gerações, acossando os sujeitos em dois espaços diferentes.

"A expiação" está dividida em três partes: "Ritual", "Fim" e "Tocaia". Os três segmentos narram diferentes momentos de uma tragédia: o suposto assassinato do personagem Orlando Spinelli pelo seu enteado, Badeco. Neste ensaio me limito à análise do segmento do meio de "A expiação" "Fim". "Fim" está inserido entre "Ritual" e "Tocaia". A história apresenta Badeco muitos anos depois de sua fuga da cena do assassinato involuntário de seu padrasto - que o maltratava - e a tentativa de vingança pelos homens da família Spinelli pela morte deste (Orlando). Badeco foge para São Paulo e assume uma nova identidade, tornando-se Jair. Ao iniciar-se a narrativa, encontramos Jair em seu leito de morte. "Fim" se configura ao longo de duas linhas temporais paralelas. A história oscila entre os estertores da morte do protagonista, que são narrados no presente, e as lembranças de sua vida após a chegada a São Paulo. Como em outros segmentos de Inferno provisório, diferentes fontes aludem às duas temporalidades distintas. O uso do itálico sinaliza o passado, enquanto a fonte padrão indica o presente. Ao usar o itálico para suscitar o passado, o discurso da memória impregna essa narrativa de uma fluidez que desaparece no momento presente da história. Assim, os diferentes tempos e as fontes associadas a estes destacam a noção de truncamento, do fim.

No início da narrativa a cidade representa uma fuga da violência arbitrária da qual Badeco/Jair era vítima enquanto vivia no espaço rural. Lá ele sofria os abusos de Orlando Spinelli, que ora o tratava como uma espécie de "filho adotado", ora o submetia a humilhações e maus-tratos físicos. A cidade, em contraste com o campo, é um espaço onde Badeco/Jair acredita poder encontrar uma forma rudimentar de cidadania através de um emprego estável, a formação de uma família própria e a constituição de um horizonte de aspirações futuras (a casa própria, educação para a prole, o lazer).

Repetindo a trajetória de inúmeros migrantes rurais que buscam nas metrópoles melhores condições de vida, Badeco/Jair gradualmente alcança os privilégios que supostamente distinguem a classe trabalhadora. Sua mobilidade social, cuja metáfora é a casa própria que ele constrói aos poucos, acontece paralelamente ao incremento dos símbolos da cidadania social na periferia metropolitana. James Holston (2008) observa que, à medida que a periferia urbana de cidades como São Paulo se urbaniza através da 
autoconstrução, essas áreas também começam a ter acesso a serviços básicos tais como água encanada, esgoto, eletricidade, escolas públicas, transporte urbano.

A propriedade privada, representada pela casa própria, é especialmente importante na (auto)percepção da cidadania e na sua execução. ${ }^{15} \mathrm{~A}$ casa própria pode conotar não somente a ascensão social mas também a performance de valores como empreendedorismo e um sentido de responsabilidade comunitária. ${ }^{16}$

"Fim" associa a expansão da família nuclear, por si um indício do incremento da estabilidade financeira do protagonista, com a expansão da casa própria através de autoconstrução, assim como a transformação da paisagem periférica em que a família de Badeco/Jair vive: "E os filhos e o progresso foram chegando: Josué, luz elétrica e rede de esgoto e água; Jairzinho, asfalto e um puxado com mais dois quartos; Orlando, supermercados e lojas e mais um andar com banheiro; Ruth, posto médico e um quarto só para ela"."

Em "Fim" a ampliação do lar empreendida por Badeco/Jair não é somente um sinônimo do avanço individual, mas também do "progresso" da esfera pública através da crescente urbanização da periferia. No entanto, como Holston (2008) elucida, esse tipo de expansão urbana não necessariamente está conectado com uma melhoria continuada e/ou estável dos direitos sociais e civis dos habitantes dessas periferias urbanas. Seguindo o molde da cidadania diferenciada, o desenvolvimento urbano periférico é muitas vezes caracterizado pela continuação de disparidades materiais que afetam a qualidade de vida dos residentes periféricos, como a educação pública inadequada, a falta de espaços públicos para o lazer, como praças e parques, um sistema de transporte público deficiente, esgoto a céu aberto e altos índices de criminalidade e de violência.

O embate entre a evolução espacial e social e o despedaçamento familiar é o drama que se desenrola em "Fim". A violência extingue aos poucos o sonho de progresso material e simbólico da classe trabalhadora, vitimando dois dos filhos de Badeco/Jair, que se envolvem com o tráfico de drogas. A violência que pouco a pouco envolve os dois jovens literalmente penetra no âmbito doméstico, contaminando todos os seus residentes e transformando a casa em um microcosmo da comunidade em geral:

15. Holston, James. Insurgent Citizenship. Disjunctions of Democracy and Modernity in Brazil, cit., p. 171.

16. Id., p. 173 .

17. RUffato, Luiz. Mamma, son tanto felice. Rio de Janeiro: Record, 2005, p. 94 (itálico no original). 
(Ruth, a caçula, parecia que ia levar adiante os estudos. Menina boa, inteligente... Mas as coisas começaram a andar erradas, os irmãos se meteram com a bandidagem do bairro, com os maus elementos, veio a brigalhada, a confusão, o entra-e-sai dia e noite, a mãe teve um ataque de nervos, noites em branco, uma tristeza danada..... ${ }^{18}$

O potencial de transformação social simbolizado pela segurança da casa própria que fertiliza outras aspirações sociais (a continuidade da educação e, por extensão, uma continuada melhoria de status material e simbólico) - é limitado pela violência social (resultado da disparidade de renda e de possibilidades de ascensão social reduzidas, para as quais o tráfico de entorpecentes se oferece como solução). "Fim" sinaliza, portanto, o fim de uma história (ou seja, "A expiação"), mas prenuncia outras narrativas sobre a violência material e simbólica decorrente da desigualdade social que motiva as migrações dos personagens trabalhadores de Inferno provisório.

\section{EL PIBE E O TRÂNSITO ENTRE ESPERANÇA E DESESPERANÇA}

Publicada em 2006, a novela El pibe, de Guillermo Saccomanno, também se concentra em espaços e personagens proletários. Embora a narrativa ocasionalmente percorra os territórios centrais da capital portenha, seu entorno principal são os bairros da classe trabalhadora: Mataderos e Floresta. A narrativa acontece principalmente em meados dos anos 50, durante a segunda presidência de Juan Domingo Perón (1952-1955), cuja figura aparece de forma indireta na novela como símbolo de uma autoridade paternalista e repressiva.

El pibe aborda a história e o contexto político argentino através das histórias individuais de vários dos personagens que transitam pelas ruas de Mataderos e de Floresta. Assim temos o pai antiperonista do personagem principal que testemunha o bombardeio pela Marinha e pela Força Aérea, em junho de 1955, contra os manifestantes reunidos na Plaza de Mayo em apoio à presidência de Perón. Além dos membros da família do personagem central, o pibe, também figuram proeminentemente na história as crianças da vizinhança, cujas batalhas de estilingue prenunciam uma juventude

18. ruffato, Luiz. Mamma, son tanto felice, cit., p. 96. 
militante durante a ditadura militar que governou o país entre 1976 e $1983 \cdot{ }^{19}$ Ao focalizar esses personagens e seus habitats, a vizinhança urbana do protagonista torna-se uma espécie de microcosmo da classe trabalhadora argentina.

A narrativa, escrita na primeira pessoa, centra-se na infância do protagonista e desenvolve-se principalmente entre os bairros de Mataderos e Floresta. Mataderos é descrito como uma zona limítrofe entre a cidade e o campo e entre legalidade e transgressão. A narrativa descreve a população de Mataderos como uma mescla de pessoas de diferentes origens, ligadas pelas condições sociais em que vivem: “Adentrándose en Mataderos, se atraviesan quintas y potreros, el barrio es un caserío habitado por los inmigrantes, los criollos y el malevaje". ${ }^{\circ}$

Em contraste, Floresta, separado de Mataderos por um córrego, é um bairro cujos habitantes têm aspirações pequeno-burguesas. Essas ambições são, entretanto, impedidas pelo status socioeconômico dos residentes, que, em sua grande maioria, trabalham em fábricas, ou são artesãos. Além disso, a precariedade da infraestrutura pública, que Floresta comparte com Mataderos, também bloqueia qualquer pretensão pequeno-burguesa.

As ruas não pavimentadas e a proximidade com o matadouro Lisandro de la Torre das duas vizinhanças revelam uma falta de investimento público nessas áreas urbanas. A descrição de ruas enlameadas e de poças de água estagnada nos dois bairros exprime no quadro urbano as consequências da cidadania diferenciada - nesse caso na forma de uma infraestrutura deficiente que, por sua vez, tem efeitos na vida diária dos residentes dos dois bairros.

Contrastando com as casas modestas e ruas de Floresta e Mataderos, está a recémfundada Ciudad Evita (estabelecida em 1947). Aqui vivem as pessoas que chegaram ao patamar da pequena burguesia graças a sua filiação ao partido peronista. Ao contrário dos bairros periféricos, onde o narrador passa a infância, Ciudad Evita sugere um certo progresso econômico que se faz aparente não no planejamento ordenado das ruas, porém no das casas: "Las calles todavía son de tierra, pero los chalecitos nuevos, con sus techos de tejas y sus jardines, le otorgan un respetable aire de prosperidad". ${ }^{21}$ No livro de Saccomanno, Ciudad Evita é símbolo de um sistema político que promove a cidadania diferenciada.

\footnotetext{
19. Saccomanno, Guillermo. El pibe, cit., p. 102.

20. Id., p. 15.

21. Id., p. 121.
} 
Enquanto o governo de Perón expandiu os direitos sociais das classes trabalhadoras (tais como pensões e assistência médica), muitos direitos políticos e civis foram limitados. Os direitos sociais eram distribuídos de acordo com um modelo assistencialista que, no entanto, exigia a lealdade ao partido peronista. Assim, alguns dos parentes do narrador conseguem comprar sua casa em Ciudad Evita graças a sua afiliação ao partido e a seu envolvimento com os programas sociais e educacionais deste, as "Unidades Básicas". Em contraste, direitos sociais como moradia adequada ou pensões são negados àqueles que se opõem ao regime: "La miseria está siempre acechando cuando alguien no se afilia al partido del régimen. Sin afiliación no hay trabajo". ${ }_{22}$ A citação sugere que aqueles que se negam a aderir à ordem política dominante (nesse caso, a peronista) são relegados às margens sociais, na medida em que não dispõem de recursos próprios. No entanto, como o substantivo "regime" sugere, essa distribuição desigual de direitos sociais não é particular ao governo de Perón, e sim faz parte do panorama social e político argentino por várias décadas.

Mataderos e seus arredores não são apenas os palcos em que a novela transcorre, mas constituem também um personagem central dentro da história. As rotinas diárias da vizinhança, a textura e os ritmos de suas ruas tornam-se parte integral do enredo. Não por acaso, El pibe abre com uma descrição do bairro, invertendo a tomada de ambientação tradicional usada na cinematografia. A novela inicia-se com uma espécie de zoom inverso ao de uma visão mais panorâmica da vizinhança, focalizando primeiro detalhes da vida diária de Mataderos - caminhões de gado transportando sua carga ao frigorífico Lisandro de la Torre:

Cruzando Directorio hacia el norte, empieza el empedrado, a diferencia de nuestras calles, que son de tierra y tienen zanjas. De aquel lado, se es más de clase media que acá, apenas una cuadra más al sur, donde el hedor del Ganado, la pestilencia de las curtiembres y el agua estancada de las zanjas enrarecen el aire, que todavía es de campo. Acá la clase media decae en un proletariado peronista con ínfulas de pequeña burguesía. ${ }^{23}$

O olhar narrativo mapeia a cidade literal e simbolicamente, criando uma topografia social que situa o leitor cronologicamente. Estamos em meados dos anos 1950 e início

22. Id., p. 70
23. Id., p. 13 .

64. LEHNEN, Leila. Cartografias da cidadania diferenciada em Luiz Ruffato e Guillermo Saccomanno 
dos 6o. A narrativa alude a vários personagens que simbolizam tanto o posicionamento temporal como sua ambientação social. Assim nos deparamos com o tio-avô anarquista do narrador e com um tio deste, um exímio acordeonista. Também aparecem vários personagens imigrantes (a bela vizinha italiana, o padeiro português, o tintureiro japonês). Esses personagens fazem referência à imigração, que tem um papel central na história argentina do século XX. Os personagens também reforçam a consciência de classe que permeia o romance - trata-se de indivíduos que pertencem à classe trabalhadora ou ao lumpemproletariado. No entanto, à diferença dos personagens de Inferno provisório, que, na sua grande maioria, não possuem consciência de classe, em El pibe vários dos personagens são conscientes de sua posição social e política na sociedade argentina. Essa consciência vai se manifestar na resistência à ditadura militar de 1973, à qual o fim de El pibe alude.

Por outro lado, a descrição dos caminhões de gado que abre a novela evoca o passado literário argentino. As cenas de gado aguardando o abate fazem referência ao conto romântico de Estebán Echevarría, "El matadero" (escrito entre 1839 e 1940 e publicado em 1871, após a morte do autor). ${ }^{24} \mathrm{O}$ conto de Echevarría fala do conflito entre os unitários, opositores ao governo do ditador Juan Manuel Rosas (1835-1852), e os federales, que apoiavam o governo de Rosas. Em El pibe, a oposição é menos entre facções políticas do que entre espaços urbanos que conotam posições sociais variadas e, por extensão, direitos diferenciados. Nesse sentido, a imagem do gado à espera do abate é também uma metáfora da falta de direitos sociais e políticos experimentada por boa parcela dos moradores dos bairros operários, que parecem prisioneiros de suas precárias condições sociais, em parte condicionadas por essa falta.

Ao mesmo tempo em que o narrador de El pibe estabelece uma correlação entre o gado aguardando o abate e os moradores de Mataderos e Floresta, ${ }^{25}$ a narrativa propõe estratégias de resistência às circunstâncias que forçam os residentes desses bairros e das classes trabalhadoras à falta de agência social e política que os favoreça. Especificamente, a novela de Saccomanno sugere que a casa própria, a educação e a escrita (em particular a produção literária e o consumo de literatura) são formas de insurgência contra a cidadania diferenciada que vitima os personagens do texto.

24. ECHEVArríA, Estebán. El matadero; La cautiva. Madrid: Cátedra, 1986.

25. Id., p. 26. 
De maneira semelhante a Inferno provisório, em El pibe a casa própria é sinônimo de respeitabilidade, representando a ascensão socioeconômica e, portanto, um aumento de direitos sociais. Em El pibe, essa associação é simbolizada pela história do maquinista (El motorman). O Maquinista é o falecido avô paterno do narrador, que trabalhava como condutor de trens. Imigrante italiano simboliza como o trabalho pode criar um empoderamento social, ainda que parcial: "con penurias y estrecheces, ahorraron para la compra de un terreno en Mataderos, a una cuadra y media del Arroyo Cildáñez, en un territorio que era más campo que ciudad. Con la colaboración de los paisanos que ya se habían afincado en el barrio, levantaron una casa que tenía bastante de rancho". ${ }^{26}$ Para o imigrante italiano, a casa própria conota uma transformação na configuração da cidadania. O lar próprio significa que ele se tornou um membro integral da comunidade (nacional). Referindo-se à importância da casa própria dentro de classes trabalhadoras brasileiras, o sociólogo Lúcio Kowarick afirma que a posse e a construção de uma residência remetem à mudança da cidadania da esfera pública à privada. Ao tornar-se dono da casa própria, o sujeito converte-se, segundo Kowarick, em um "cidadão privado": "aquele que, com seu esforço e perseverança, venceu na vida, pois ergueu durante muitos e penosos anos a sua casa própria. Núcleo de sociabilidade baseada em contatos primários, ela encarna uma realização de um projeto individual de existência: a segurança verdadeira e simbólica da propriedade". ${ }^{27}$ Embora as palavras de Kowarick referenciem o contexto brasileiro, pode-se argumentar que a segurança material que a posse de um imóvel significa transcende a conjuntura nacional. A ideia de que a casa própria represente a inserção em uma comunidade, o fortalecer dos laços sociais dentro desta, aplica-se tanto ao contexto brasileiro como ao argentino.

Semelhantemente aos personagens de "Fim", para o maquinista a expansão e a melhoria do domicílio oferecem, teoricamente, uma saída futura para as restrições socioeconômicas que ele e sua família enfrentam no presente. A casa denota estabilidade. Assim, para o maquinista é importante que ela seja construída de tijolos, um material que simboliza solidez e permanência. No entanto, após a sua morte, a residência que o maquinista construiu tijolo por tijolo ("mi padre cuenta que el abuelo volvía caminando del trabajo y en el trayecto siempre juntaba ladrillos que servían para terminar la casa") ${ }^{28}$

\footnotetext{
26. Id., p. 36.

27. KowArick, Lúcio. A espoliação urbana. Rio de Janeiro: Paz e Terra, 1980, p. 94.

28. SACCOMAnNo, Guillermo. El pibe, cit., p. 37.
} 
começa a deteriorar-se. Se durante a vida do maquinista a casa fora mantida em perfeita ordem, após a sua morte e a decadência social gradual dos três filhos mais jovens que residem na casa, o domicílio é negligenciado:

desde la muerte del abuelo motorman sus hijos no han sido capaces de revocar la medianera, pintar una pared, emparchar una gotera, aceitar una puerta. [...] está también la mugre que se junta en todas las partes. [...] Y sus hermanos están orgullosos de esta vida que llevan, como si fuera un signo de hombría revolcarse en la mugre. ${ }^{29}$

A ruína gradual da residência reflete a decadência dos habitantes atuais. Nenhum dos três homens tem a mesma ética de trabalho que o pai ou o irmão mais velho (o pai do narrador). Ao contrário, eles são vítimas do alcoolismo e dos jogos de azar. Os três trabalham em subempregos que não têm o prestígio social que a posição de maquinista tem e que permitiu a inserção do pai deles no tecido nacional e, em termos locais, na comunidade. A degradação na esfera privada significa um afastamento gradual do ideal de cidadania emblematizado pelo maquinista. A ruína domiciliar conota a aproximação dos três homens da esfera da transgressão social e moral. De fato, mais tarde um dos irmãos termina na prisão e os outros dois morrem de alcoolismo.

Além da casa própria, a educação também pode servir como uma ferramenta para combater a cidadania diferenciada e a falta de direitos sociais que esta implica. O pai do narrador, embora tendo pouco dinheiro, investe regularmente parcela do seu salário em livros. Para ele, os livros são uma "estrategia de ascenso social". ${ }^{\circ}$ Nesse sentido, os livros significam tanto uma despesa como um investimento: o ganho é simbólico, mas por vezes também é mais concreto, pois ao final do mês, quando não sobra dinheiro em casa, o pai tem que vender seus amados livros: "vas a ver, dice, los libros no son sólo alimento espiritual". ${ }^{31}$ Apesar da postura pragmática, o pai sente-se entristecido pela necessidade de vender seus livros. Para ele, essa venda significa a comercialização da agência simbólica (o conhecimento) - que os livros oferecem.

A falta de agência decorrente da necessidade material é destacada na descrição do que acontece após a venda dos livros. Depois de deixar a livraria, pai e filho caminham

\footnotetext{
29. Id., pp. 131-2.

30. Id., p. 147 .

31. Id., p. 153 .
} 
até a avenida Corrientes, uma das principais vias de Buenos Aires, conhecida por seus locais de entretenimento. É uma noite de sábado e a rua está repleta de vida. No entanto, o narrador observa que: "nosotros no hemos sido invitados". ${ }^{22}$ Apesar de suas aspirações e esforços de melhoria social, El pibe deixa claro que a classe trabalhadora tem uma existência precária, oscilando à beira da pobreza. Os membros desse segmento social têm que desenvolver diferentes estratégias para lidarem com os efeitos da cidadania diferenciada. Para o pai do narrador, a primeira tática que este desenvolve para lidar com os mecanismos de exclusão social e simbólica que enfrenta é a militância política, seguida pela fé na educação. Mais tarde, a escrita é o antídoto contra o esquecimento tanto da sua história pessoal como da história nacional. A novela de Saccomanno sugere que sem memória - isto é, sem a escrita - a agência não é possível. Isso se torna particularmente evidente no final do livro. O fim de El pibe salta ao período do golpe militar de 1976. A novela descreve como a cidade de Buenos Aires (e, por extensão, a nação) foi transformada em um espaço perigoso, no qual a cidadania efetivamente foi apagada devido ao estado de exceção ${ }^{33}$ imposto pelas autoridades militares. Nesse ambiente, a memória é um dos poucos instrumentos de resistência que o cidadão tem contra a violência de Estado:

Una mañana (después del golpe de 76), mientras mi padre espera un colectivo, un Falcon verde frena en la parada. Cuatro tipos secuestran a una chica. Mi padre forceja con ellos. Uno de los tipos lo golpea con una pistola. Mientras la cargan en el auto, la chica grita un teléfono. Mi padre vuelve a casa llorando. Olvidó el número. ${ }^{34}$

O esquecimento revela a impotência não somente do pai do narrador, mas de uma nação inteira que é forçada a ignorar os abusos cometidos pelos agentes do Estado.

Ao saltar cronologicamente dos anos 1950 a meados dos anos 70, a voz narrativa estabelece um contínuo de privação de direitos políticos e civis. Sugere-se que a memória pode ajudar a combater a impotência política e social da qual os personagens da narrativa são vítimas. E a memória torna-se possível através da escrita.

\footnotetext{
32. Id., p. 154.

33. agamben, Giorgio. State of Exception. Chicago: University of Chicago Press, 2005.

34. Id., p. 155.
} 
Para o pai e, por extensão, para o filho, cuja história se está lendo, a literatura fornece como que alívio contra a privação de vários tipos de direitos. Escrever e ler servem tanto para melhor compreender, como para transcender o meio social sufocante de Mataderos e de Floresta. O pai escreve uma novela, a qual, como a narrativa sugere, é completada pelo filho. Trata-se possivelmente da história que estamos lendo. Essa crônica da vida cotidiana da classe trabalhadora resgata essas vidas do anonimato ao qual geralmente estão condenadas.

O texto de Saccomanno propõe a escrita como um meio de recuperar as histórias invisíveis do proletariado argentino, não somente para os personagens do texto, mas também para os leitores deste. A novela resgata as histórias invisíveis do proletário argentino. Ao lermos essas histórias, nós indiretamente participamos dessa operação. A escrita que emerge dentro das fissuras da cidadania diferenciada torna-se uma expressão do que Holston denomina a "cidadania insurgente", a criação de uma agência em espaços marginais e por sujeitos marginalizados, periféricos (tanto no sentido social, como no territorial). Nesse contexto, a voz da criança que ressoa em El pibe - e que vai se transmutar em uma voz adulta ao final da narrativa - é emblemática dessa esperança, pois proporciona uma arena para a memória das classes trabalhadoras.

Em comparação, os sujeitos das narrativas de Ruffato na sua maioria estão presos em existências medíocres ou mesmo miseráveis. Vários desses personagens lutam para transcender não só o seu espaço geográfico, mas também as suas condições sociais. No entanto, apesar do desencanto que satura as histórias de Inferno provisório, o título do ciclo também alude à possibilidade de um resgate - talvez também através da vocalização da cidadania diferenciada uma consciência insurgente possa ser gerada.

Leila Lehnen é Professora de Literatura na University of New Mexico. 